\title{
1 Geological Observations on Large Earthquakes along the 2 Himalayan Frontal Fault near Kathmandu, Nepal
}

3

$4 \quad$ Steven G. Wesnousky ${ }^{1}$

$5 \quad$ wesnousky@unr.edu*

6 Yasuhiro Kumahara $^{2}$

$7 \quad$ kumakuma@hiroshima-u.ac.jp

8 Deepak Chamlagain $^{3}$

9 deepakchamlagain73@gmail.com

10 Ian Pierce ${ }^{1}$

11 ian@nevada.unr.edu

12 Alina Karki ${ }^{3}$

13 karkialina26@gmail.com

14

15

16

17

Dipendra Gautam ${ }^{4}$ strdyn@yahoo.com Reno 89557, USA Hiroshima, Hiroshima 739-8524, Japan

* Corresponding author Hazard.
${ }^{1}$ Center for Neotectonic Studies and Seismological Laboaratory, University of Nevada,

${ }^{2}$ Graduate School of Education, Hiroshima University, 1-1-1, Kagamiama, Higashi-

${ }^{3}$ Department of Geology, Tri-Chandra Multiple Campus, Kathmandu, Nepal.

${ }^{4}$ Centre for Disaster and Climate Change Studies, Kathmandu, Nepal

Keywords: Himalaya, Earthquakes, Seismology, Tectonics, Paleoseismology, Seismic 


\section{ABSTRACT}

The 2015 Gorkha earthquake produced displacement on the lower half of a shallow

35 decollement that extends $100 \mathrm{~km}$ south, and upward from beneath the High Himalaya and

36 Kathmandu to where it breaks the surface to form the trace of the Himalayan Frontal

37 Thrust (HFT), leaving unruptured the shallowest $\sim 50 \mathrm{~km}$ of the decollement. To address

38 the potential of future earthquakes along this section of the HFT, we examine structural,

39 stratigraphic, and radiocarbon relationships in exposures produced by emplacement of

40 trenches across the HFT where it has produced scarps in young alluvium at the mouths of

41 major rivers at Tribeni and Bagmati. The Bagmati site is located south of Kathmandu

42 and directly up dip from the Gorkha rupture, whereas the Tribeni site is located $\sim 200 \mathrm{~km}$

43 to the west and outside the up dip projection of the Gorkha earthquake rupture plane. The

44 most recent rupture at Tribeni occurred $1221-1262$ AD to produce a scarp of $\sim 7 \mathrm{~m}$

45 vertical separation. Vertical separation across the scarp at Bagmati registers $\sim 10 \mathrm{~m}$,

46 possibly greater, and formed between 1031 - 1321 AD. The temporal constraints and

47 large displacements allow the interpretation that the two sites separated by $\sim 200 \mathrm{~km}$ each

48 ruptured simultaneously, possibly during $1255 \mathrm{AD}$, the year of a historically reported

49 earthquake that produced damage in Kathmandu. In light of geodetic data that show 20

$50 \mathrm{~mm} / \mathrm{yr}$ of crustal shortening is occurring across the Himalayan front, the sum of

51 observations is interpreted to suggest that the HFT extending from Tribeni to Bagmati

52 may rupture simultaneously, that the next great earthquake near Kathmandu may rupture

53 an area significantly greater than the section of HFT up dip from the Gorkha earthquake,

54 and that it is prudent to consider that the HFT near Kathmandu is well along in a strain

55 accumulation cycle prior to a great thrust earthquake, most likely much greater than

56 occurred in 2015. 


\section{1. Introduction}

61 The Mw 7.8 Gorkha (Nepal) earthquake of April 25 was followed on May 12 by an

62 Mw 7.3 aftershock (Fig. 1). The sequence released a total seismic moment of $\sim 7-8 \mathrm{x}$

$6310^{20} \mathrm{Nm}$ (NCEDC, 2014). Geophysical studies show the sequence to be the result of

64 thrust motion on an $\sim 150 \times 50-80 \mathrm{~km}^{2}$ fault plane elongated along strike of the Himalaya

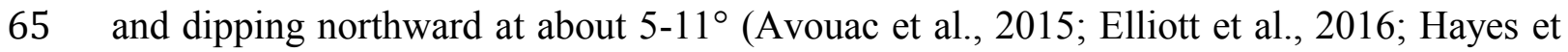

66 al., 2015). Coseismic slip on the fault plane reached a maximum of $\sim 6 \mathrm{~m}$ (Hayes et al.,

672015 ) and $\sim 2.5$ meters when averaged over the fault plane. The earthquake ruptured on

68 the lower half of a shallow decollement that extends $100 \mathrm{~km}$ south, and upward from

69 beneath the High Himalaya to where it produces the trace of the HFT, leaving unruptured

70 the shallowest $\sim 50 \mathrm{~km}$ of the decollement (Angster et al., 2015). The presence of fault

71 scarps in young alluvium along strike of the HFT in both Nepal and India attests to the

72 occurrence of past earthquakes that have ruptured the up dip portion of the HFT (e.g.,

73 Bollinger et al., 2014; Kumar et al., 2006; Lave et al., 2005). Here geological

74 observations are presented at two sites along the HFT place limits on the timing and size

75 of past earthquake surface rupture displacements up dip and to the west of the Gorkha

76 rupture sequence.

77 The two sites, Tribeni and Bagmati, are located along the HFT where it strikes

78 across the mouths of the Narayani and Bagmati Rivers (Fig. 1). The Bagmati site is

79 located south of Kathmandu and directly up dip from the Gorkha rupture, whereas the

80 Tribeni site is $\sim 50 \mathrm{~km}$ west of the Gorkha mainshock and located outside the up dip

81 projection of the Gorkha earthquake rupture plane (Angster et al., 2015; Avouac et al.,

82 2015; Hayes et al., 2015).

\section{2. Observations}

84 2.1. Tribeni

85 Displacement on the HFT has here elevated fluvial terraces above the Narayani River

86 (Fig. 2a). The youngest two uplifted terrace surfaces are T1 and T2 and truncated on the

87 west by the HFT. We excavated two trenches across the HFT where it bounds each of

88 the respective surfaces (Fig. 2a). The scarp that truncates the T1 surface and across which 
the trench B was excavated is interpreted to be the result of displacement during the most recent surface rupture earthquake. Coarse stratigraphy and lack of organic material for dating compromised the utility of Trench

B. (Supplementary Material, Section S1,

92 Figs. S1, S2, and S3). Vertical separations across the scarps bounding the younger T1 93 and the relatively older and higher T2 surface are $\sim 7$ and $\sim 14 \mathrm{~m}$, respectively. We focus

94 attention here on the exposure across the multiple-event T2 scarp.

95 The photo in Fig. 3a of the trench site prior to excavation illustrates the character of 96 the HFT scarp where it truncates the T2 surface. A sketch of the exposure is presented in

97 Fig. 4a. Strands of the HFT cut and deform sedimentary layers in the lower western 98 portion of the trench. The stratigraphy of the hanging wall is defined by a sequence of 99 fluvial beds inclined westward at an angle of $\sim 20^{\circ}$, rolling to yet steeper angles near the 100 fault contact, to form a dip panel truncated by several strands of the HFT that dip east. 101 The main basal strand of the fault zone is approximately planar and dips at $\sim 30^{\circ}$ in the 102 exposure, while the upper strand that bounds unit 4 dips at about $20^{\circ}$ at the base of the 103 exposure and lessens to $<10^{\circ}$ at its upward extent. The basal unit 1 of the dip panel is 104 coarse rounded river gravel most likely deposited by an earlier course of the adjacent 105 Narayani River. It is overlain conformably by an alternating sequence of fine sand and 106 silty fine sand beds (units 2 and 3) earlier deposited as flood and overbank deposits of the 107 Narayani River. Strata on the footwall below the east dipping strands of the fault are the 108 same, though individual beds of unit 2 on the foot and hanging wall are not observed to 109 match. The upper portion of the shear zone (unit 4) is composed of faulted, sheared, and 110 rotated layers and blocks of sediment similar to unit 2. The basal portion of the shear 111 zone (unit 5) is very fine sand lacking bedding. Unit 6 is the highest, youngest, and only 112 unfaulted layer in the exposure. It is generally massive, except near its base where 113 discontinuous lenses of rounded pebbles are present, and displays an erosive lower 114 contact above the fault zone. Unit 6 thus aggraded subsequent to the deformation that 115 caused the shear zone and accompanying dip panel. In this regard, the base of unit 6 116 marks a deformation event horizon. Unit descriptions are further documented in 117 Supplementary Table S1 and a photo log of the exposure is provided in Supplementary 118 Fig. S4.

119 Detrital charcoal samples present in units both above and below the event horizon 
120 were collected for radiocarbon analysis. The ages and sample locations are depicted in

121 Fig. 4a. Supplementary Table S2 records the original laboratory analysis for each

122 sample. The ages are also plotted graphically in Fig. 5a in stratigraphic order of the beds

123 from which they were collected. The ages of samples immediately above and below the

124 event horizon are nearly identical. Application of OxCal v4.2.4

125 ((https://c14.arch.ox.ac.uk/oxcal/OxCal.html) Bronk, 2009) to the observed sequence of

126 ages places the age of a scarp forming event at between 1221 AD and 1262 AD (labeled

127 'Displacement Horizon' in Fig. 5a). Surveyed profiles of the scarp and trench exposure

128 show that vertical separation across the dip panel and scarp is $\sim 13-14 \mathrm{~m}$, and the

129 presence of the lower T1 terrace bounded by the same scarp (Fig. 2a) suggests that it is

130 the result of two or more earthquakes. When viewing the trench exposure (Fig. 4a), at

131 least 5 to $6 \mathrm{~m}$ of the entire vertical separation across the scarp may be attributed to that

132 occurring between $1221 \mathrm{AD}$ and $1262 \mathrm{AD}$ : Sediments on the footwall are flat-lying,

133 which rules out any contribution to the observed scarp from faulting further west of the

134 exposure, and undeformed dip panel is observed to extend vertically 5 to $6 \mathrm{~m}$ to the east.

135 The $\sim 7 \mathrm{~m}$ vertical separation observed across the scarp bounding the lower T1 surface at

136 Trench B (Figures $2 \mathrm{a}$ and S1 and S2) is considered to have occurred at the same time

137 It seems unlikely, though cannot be strictly ruled out, that two earthquake

138 displacements on the faults exposed in the trench occurred very closely spaced in time

139 ( $<50$ years) to produce the $\sim 13-14 \mathrm{~m}$ of vertical separation across the fault. We

140 speculate that the $1221-1262$ event is the youngest surface displacement recorded at

141 Tribeni and an older rupture is recorded higher up on the T2 scarp (Fig. 4a, lower). The

142 speculation is driven by observations that (1) no additional colluvium is observed on the

143 scarp above the growth stratigraphy (Fig. 4a) which could be expected with sudden

144 growth of the scarp from a fault displacement younger than the 1221-1262 event and

145 higher up on the scarp, (2) there are to our knowledge no historical accounts since 1255

146 AD (Pant, 2002)) that describe the extent and degree of damage we would expect for an

147 earthquake with the large coseismic offsets interpreted in the Tribeni trench, and (3)

148 analogue sand-box models that show thrust fault development is commonly characterized

149 by in-sequence propagation of forward thrusts (e.g., Ellis et al., 2004).

150 2.2. Bagmati 
151 Here displacements on the HFT have truncated and uplifted fluvial deposits at the 152 mouth of the Bagmati River. The youngest uplifted terrace deposits are labeled T1 and 153 T2 in Fig. 2b, and the star marks the location where we excavated a trench across the 154 fault scarp. The scarp bounding the younger T1 surface is $\sim 5 \mathrm{~m}$ high whereas scarp 155 heights along the older T2 surface are generally 10-15 m or greater. A photo of the scarp 156 truncating the T1 surface at the trench site is shown in Fig. 3b. The trench log is shown in 157 Fig. 4b, and Supplementary Figs. S5 and S6 provide photo logs of the exposure. The 158 deformation style and sediment types are similar to those observed at Tribeni. The HFT is 159 observed to displace and deform sedimentary layers in the lowest southwestern portion of 160 the trench. The stratigraphy of the hanging wall is defined by a sequence of fluvial beds 161 that are near horizontal at the northeast limit of the exposure and then bend downward $162 \sim 25^{\circ}$ to form a dip panel that is truncated by the HFT. The HFT dips northeastward at $163 \sim 30^{\circ}$ near the base of the trench and lessens to $<10^{\circ}$ at its shallowest extent. The basal 164 unit (1) of the dip panel is coarse rounded river gravel most likely sourced from the 165 Bagmati River. It is capped by an alternating sequence of fine sand and silty fine sand 166 beds (units 2 and 3) interpreted to be flood and overbank deposits of the Bagmati River. 167 The beds of the dip panel are overlain by a sequence of unfaulted horizontal beds (units 1684,5 , and 6) that accumulated subsequent to displacement on the HFT and creation of the 169 dip panel. The lowest of the units (4) is comprised of pebbles and small cobbles enriched 170 in sand at its base and displays an erosive lower contact. The higher flat-lying units (5 171 and 6) are very fine silty and clay bearing sand, which are viewed as growth stratigraphy 172 accumulating as the result of erosion and sediment transport from the adjacent drainage 173 (Fig. 3b), subsequent to creation of the dip panel. Local flood events from the adjacent 174 drainage also appear responsible for the gravel-filled channel units (7 and 9). Likewise, 175 the significant erosion of unit 2 along the higher reaches of the dip panel may be 176 attributed to development of the adjacent drainage subsequent to development of the 177 scarp.

178 Detrital charcoal was present and sampled from layers of the dip panel and 179 overlying growth stratigraphy. The results are plotted in stratigraphic sequence in Fig. 5b 180 and the original radiocarbon laboratory analyses summarized in Table S2. But for 181 sample B-2 that was radiocarbon dead, the radiocarbon ages follow stratigraphic order. 
182 Units 2 and 3 (containing samples B-19, 13, 8, 7, and 6) were deposited prior to 183 deformation and creation of the dip panel while units 4 to 8 (containing samples B-4, 15, $18411,14,3$, and 18) were deposited subsequently. The deformation event horizon thus falls 185 between the beds of units 3 and 4 containing samples B-6 and B-4, respectively, and so 186 marks the time of surface rupture and scarp formation. Application of OxCal v4.2.4 187 ((https://c14.arch.ox.ac.uk/oxcal/OxCal.html) Bronk, 2009) places fault rupture and 188 creation of the scarp at between 1031 AD and 1321 AD. The surface scarp height at the

189 trench is $\sim 5$ meters. The vertical separation resulting from tectonic deformation is more 190 aptly described as $10 \mathrm{~m}$ when fill on the footwall wall that occurred subsequent to 191 faulting and tilting of the dip panel is taken into account (Fig. 4b). In these regards, $10 \mathrm{~m}$ 192 of vertical uplift occurred across the scarp during the period 1031 AD and 1321 AD. 193 Limits imposed upon excavating further to the west and deeper prevented exposing the 194 dip panel to its deepest extent and the full thickness of the growth stratigraphy on the 195 footwall. That the dip panel continues below the lowest most exposed fault strand 196 requires that there is at least one more fault strand below the base of the exposure, that 197 the $10 \mathrm{~m}$ measure of vertical separation is a minimum, and permits that the dip panel is 198 the result of more than one displacement between 1031 AD and 1321 AD.

\section{3. Discussion: past and future rupture behavior}

200 3.1. Size of earthquake recorded at Tribeni

201 The relationships in the trench at Tribeni (Fig. 4b), located southwest of Kathmandu and 202 outside the up-dip projection of the 2015 Gorkha rupture (Fig. 1), are evidence that 203 earthquake displacement has produced surface rupture resulting in a scarp of at least $\sim 5$ 204 m vertical separation between 1221 and 1262 AD (Fig. 5a). Uncertainties are large when 205 trying to estimate the size of a past earthquake from a single measurement of vertical 206 separation. In addition to being limited to a single observation, assumptions must be 207 made bearing on the style of deformation and dip of causative fault for which, in this 208 case, we cannot be not certain that the dip observed in the trench exposure extends 209 without change beneath the entire scarp. The dip of the shear zone is about $20^{\circ}-30^{\circ}$ at the

210 base of the Tribeni trench. To approximate the fault displacement required to produce the 211 dip panel and $\sim 5-7$ m of vertical separation observed across the Tribeni scarp (Figs 4a 212 and Supplementary S2), we assume a $15^{\circ}-45^{\circ}$ range of dips to reflect the uncertainty 
213 in our knowledge of the dip as it extends below the trench exposure, consistent with 214 Andersonian mechanics (Anderson, 1951). When it is assumed the slip vector is 215 perpendicular to the Tribeni scarp, the amount of slip on a fault dipping at an angle 216 between $15^{\circ}$ and $45^{\circ}$ required to produce 5 to $7 \mathrm{~m}$ of vertical separation is between $7 \mathrm{~m}$ to $21727 \mathrm{~m}$, respectively. The strike of the scarp at Tribeni $\left(\sim 160^{\circ}\right)$ is oblique to the direction 218 of convergence $\left(\sim 190^{\circ}\right)$ indicated by geodesy (e.g., Ader et al., 2012 and Fig. 1). If 219 coseismic slip at the scarp shares the same obliquity, the required amount of slip to 220 produce the 5 to $7 \mathrm{~m}$ vertical separation would approach double these values. These 221 approximated values of slip viewed in the context of empirical scaling laws relating 222 average coseismic slip, rupture length, and moment magnitude $\mathrm{Mw}$ constructed from data 223 sets comprising hundreds of historical dip-slip earthquakes (Blaser et al., 2010; Leonard, 224 2010, 2014; Strasser et al., 2010), are commensurate to that expected for earthquakes of 225 magnitude ranging between $\mathrm{Mw} \sim 8.5$ and $>9.0$ with rupture lengths of $400 \mathrm{~km}$ to $>900$ $226 \mathrm{~km}$. If the fault steepens to vertical dip beneath the scarp, the lesser measure of $5 \mathrm{~m}$ 227 vertical separation should approximate the fault slip needed to produce the observed dip 228 panel. In this case, the same empirical scaling laws point to a causative earthquake in the 229 broad range of $\mathrm{Mw} \sim 8.2$ to 8.4 with a $200-350 \mathrm{~km}$ rupture length. The scaling laws are 230 developed for estimates of average coseismic slip. It is possible that the slip at Tribeni 231 was actually maximum along strike of the earthquake rupture, in which case the prior 232 estimates of $\mathrm{Mw}$ and rupture length might be considered overestimates. This concern is

233 tempered by the observation that our $5 \mathrm{~m}$ measurement of vertical separation is a 234 minimum estimate of coseismic offset. So, while such estimates are coupled with large 235 uncertainty, it is reasonable to consider that the last scarp producing earthquake at Tribeni 236 was associated with a rupture that extended hundreds of kilometers along the HFT, a 237 distance greater than that between Tribeni and Bagmati.

238 3.2. Extent of rupture east of Tribeni to Bagmati

239 The Bagmati trench site is located about $200 \mathrm{~km}$ east of Tribeni and directly up-dip 240 of the 2015 Gorkha earthquake rupture (Fig. 1). The broader 1031 - 1321 AD temporal 241 constraint on the timing of scarp formation at Bagmati encompasses the $1221-1262$ AD 242 age of most recent scarp formation at Tribeni (Fig. 5b). Given the temporal overlap and 243 the prior discussion showing that the earthquake producing the Tribeni scarp may be 
244 considered to have produced surface rupture on order of hundreds of $\mathrm{km}$ in length along

245 the HFT, it is reasonable to suggest that the Bagmati and Tribeni sites ruptured 246 simultaneously between 1221 - 1262 AD. The large vertical separation observed across 247 the scarp at Bagmati $(>10 \mathrm{~m})$ is consistent with the interpretation, albeit the Bagmati 248 scarp may be the result of more than one earthquake during the period $1031-1321 \mathrm{AD}$, a 249 topic we return to later in the discussion.

250 3.3. Extent of rupture east of Bagmati

251 Shifting attention to about $25 \mathrm{~km}$ east of Bagmati, there exist two prior 252 paleoearthquake studies, one reported by Lave et al. (2005) at Marha Khola and another 253 reported in the papers of Sapkota et al. (2013) and Bollinger et al. (2014) at Sir Khola 254 (Fig. 1). Marha Khola is just $7 \mathrm{~km}$ west of Sir Khola. At Sir Khola, surface rupture was 255 recognized for the great $1934 \mathrm{M} \sim 8.4$ Bihar earthquake and along with geomorphic 256 observations led to interpretation that it ruptured at least the $150 \mathrm{~km}$ section of the HFT 257 indicated in red on Fig. 1. No support for surface rupture in 1934 is provided by our 258 analysis of the HFT scarp at Bagmati, which may be interpreted to place a firm bound on 259 the western extent of surface rupture during 1934. The Sir Khola site was also 260 interpreted by Sapkota et al. (2013) to preserve evidence of prior surface rupture of an 261 historically reported earthquake in 1255 AD. The 1255 AD age at Sir Khola falls within 262 the 41-year (1221 AD to 1262 AD) window allowed by radiocarbon for the offset we 263 observe at the Tribeni site. Coupled with the large displacement event bracketed more 264 loosely between $1031 \mathrm{AD}$ and 1321 at the Bagmati site, the observations would then 265 appear to allow a single rupture to have extended a total of $225 \mathrm{~km}$ between Sir Khola 266 and the Tribeni Site. The interpretation though is complicated by the observations of 267 Lave et al. (2005) at Marha Khola ( $\sim \mathrm{km}$ west of Sir Khola and closer to Bagmati and 268 Tribeni, Fig. 1).

269 Lave et al. (2005) interpreted the occurrence of a single earthquake displacement at 270 Marha Khola on the order of $17 \mathrm{~m}$ to have occurred at about $1100 \mathrm{AD}$, well before the $2711255 \mathrm{AD}$ age interpreted for the penultimate surface rupture at Sir Khola by Sapkota et 272 al. (2013). Our reanalysis of the radiocarbon data reported in Supplementary Table S1 273 of Lave et al. (2005) with Oxcal v4.2.4 is shown in Fig. 5c and places a formal 95\% 274 bound on the event horizon observed at Marha Khola at between 1022 and 1102 AD. 
275 Additionally, Lave et al. (2005) interpret the stratigraphy to indicate that the 1934 Bihar 276 earthquake did not produce surface rupture a Marha Kohla. Sapkota et al. (2013) 277 discount these interpretations of Lave et al. (2005). The reasons for disregarding Lave et 278 al.’s (2005) analysis are worth considering.

279 Sapkota et al. (2013) discount the 1100 AD event interpreted by Lave et al. (2005) 280 because of historical accounts of a large earthquake that produced significant damage and 281 several thousand deaths in Kathmandu in 1255 AD (Pant, 2002). The knowledge of the 2821255 AD earthquake was emplaced as an a priori input by Sapkota et al. (2013) in their 283 analysis of radiocarbon ages to assess the timing of the paleoearthquake observed in their 284 trench. The stratigraphy in their studied exposure at Sir Khola though provided 285 radiocarbon samples only in sediments deposited subsequent to the displacement 286 attributed to the $1255 \mathrm{AD}$ earthquake, and not before. An examination of their reported 287 ages using Oxcal 4.2.4 in absence of any Bayesian bias shows the data they report in their 288 Fig. S3C to very loosely limit the timing of the event horizon attributed to 1255 AD at 289 between 644 and 1210 AD, a span that does not include 1255 AD (Fig. 5d). The 290 radiocarbon stratigraphy at Lave et al.'s (2005) Marha Khola site is in contrast quite 292 horizon attributed to the $\sim 1100$ AD event (Fig. 5c). In the context of these preceding 293 observations, the data at Marha Khola and Sir Khola are compatible with each 294 experiencing simultaneous rupture between 1022 and 1102 AD, and Lave et al's (2005) 295 earlier speculation that the $\sim 1100 \mathrm{AD}$ paleoearthquake might correspond to a 296 paleoearthquake surface rupture reported $\sim 250 \mathrm{~km}$ to the east near the Nepal border may 297 remain valid (Nakata et al., 1998; Upreti et al., 2000). To this discussion, we add the 298 suggestion that our result at Tribeni that defines a surface rupture event between 1221 $299 \mathrm{AD}$ and $1262 \mathrm{AD}$ is perhaps a better, less ambiguous, candidate for the $1255 \mathrm{AD}$ 300 historical earthquake than is the Sir Khola site. Radiocarbon dating thus allows that this 301 proposed 1221 - 1262 AD event at Tribeni ruptured $200 \mathrm{~km}$ westward through Bagmati, 302 but whether or not the rupture extended another $25 \mathrm{~km}$ to the east to Sir Khola is 303 debatable.

304 For convenience of presentation, the 1221 AD to 1262 AD displacement observed 305 at Tribeni (Fig. 5a) and the 1022 to 1102 AD earthquake reported at Marha Khola (Fig. 
306 5c) are herein referred to as the $1255 \mathrm{AD}$ and $1100 \mathrm{AD}$ earthquakes, respectively.

\subsection{Contemporaneity of Rupture at Bagmati and Tribeni?}

If one follows the interpretation that the scarp at Bagmati is the result of a single earthquake, the broad and formal temporal bounds on the displacement horizon at Bagmati (1031- 1321 AD) (Fig. 5b) also allow another scenario whereby displacement at Bagmati did not occur contemporaneously with Tribeni in 1255 AD but instead with the $\sim 1100 \mathrm{AD}$ event event at Marha Khola, and possibly Sir Khola too (Figs. $5 \mathbf{c}$ and d). If so, one encounters the question of why there is such a long hiatus in deposition at Bagmati subsequent to a hypothesized $\sim 1100$ AD event (Fig. 5b). It is difficult to reconcile the hiatus with the expectation that deposition on the footwall (arising from scarp degradation and local scarp incision) would begin soon after creation of a scarp (e.g., Sapkota et al., 2013). It is more intuitive that the hiatus is the result of an earlier abandonment of the surface across which the Bagmati scarp cuts, either from a change in the course or an earlier incision of the Bagmati River. This latter idea finds some support in the observation that the footwall of the Bagmati scarp is now inhabited and sits $\sim 8 \mathrm{~m}$ and more above the present course of the Bagmati River. The incision, all or in part, or a significant change in stream course may have occurred well before the scarp forming event at Bagmati. Albeit one cannot disprove with the radiocarbon data available that Bagmati ruptured simultaneously with Marha Khola in $~ 1100$ AD, the geological context provides a reasonable basis to interpret that, if indeed Bagmati ruptured simultaneous with one of the adjacent sites, it more likely ruptured with the $1255 \mathrm{AD}$ event at Tribeni rather than with the $\sim 1100 \mathrm{AD}$ event at Marha Khola.

The observed hiatus in deposition at Bagmati subsequent to a hypothesized $\sim 1100$ AD event (Fig. 5b) may though be apparent if the scarp at Bagmati is the result of multiple earthquakes. In this case, the observed hiatus in deposition may be considered to be the consequence of our inability to excavate deeper and possibly observe the presence of older deformed packages of growth stratigraphy (Fig. $\mathbf{4 b}$ ). The conjecture leads to other possible scenarios whereby the $\sim 1100$ AD rupture documented at Marha Khola and the $1255 \mathrm{AD}$ event at Tribeni each extended and overlapped at Bagmati, or all displacement at Bagmati occurred simultaneously with the $\sim 1100$ AD earthquake.

\subsection{Limit on westward extent of Mw 8.4 1934 Bihar earthquake}


Shifting attention back to the Mw 8.4 1934 Bihar earthquake, the lack of deformation in sediments post-dating and overlying the Bagmati surface rupture that occurred between 1031 - 1321 AD may be viewed to place a firm western limit on the extent of surface rupture during the 1934 event (Figs. 4b and 5b). Sapkota et al. (2013) also interpret that the lack of 1934 rupture at the Marha Khola site of Lave et al. (2005) is not inescapably demonstrated because two thrusts emerging near the base of a $4 \mathrm{~m}$-high

343 scarp studied along a river cut are not sealed by dated deposits. Yet, Lave et al. (2005)

344 studied an additional two trench exposures within $\sim 100 \mathrm{~m}$ of the river cut and each of 345 these displayed 1 to $2 \mathrm{~m}$ of unbroken sediments post-dating 1100 AD and predating 3461934 over the active strands of the fault (Figs. 2 and 3 in Lave et al. (2005)). In this

347 regard, the possibility that Marha Khola actually marks the western limit of rupture 348 during the 1934 Bihar earthquake should not be ruled out.

\section{3.6. West of Tribeni}

350 Moving focus to the west of Tribeni, there are few observations and studies to bear 351 on the past history of large earthquakes in Nepal. Mugnier et al. (2005), about $150 \mathrm{~km}$ 352 west of Tribeni (Fig. 1), report a radiocarbon sample of $775 \pm 35$ Yr BP (1190 - 1285 $353 \mathrm{AD})$ taken from a terrace that is displaced vertically $8 \mathrm{~m}$ by one or more events by the 354 HFT. The limiting terrace age encompasses the timing of the $1221 \mathrm{AD}$ to $1262 \mathrm{AD}$ 355 surface rupture event we observe at Tribeni, and they speculated the terrace offset may in 356 part record the $1255 \mathrm{AD}$ earthquake that produced damage in Kathmandu (Pant, 2002). 357 This observation and the large displacement at Tribeni certainly allow one to consider 358 that the earthquake that produced the scarp at Tribeni extended 150 kilometers westward, 359 and maybe significantly more.

Ambraseys and Jackson (2003) followed Jackson (2002) in interpreting historical 361 reports to suggest the occurrence of an $M>8$ earthquake in western Nepal in 1505. It

362 has since often been speculated that the earthquake was the result of displacement on the 363 HFT (Avouac et al., 2015; Bilham, 2004; Bollinger et al., 2016), though observational 364 support arises primarily from felt reports quite distant to the north of the Himalaya in 365 Tibet between Guge and Gungthang and the collapse of some tall buildings in Agra (Fig. 366 1). As such, it may be considered that the release of stress in 1505 could be a factor in 367 limiting the westward extent of the next large surface rupture earthquake south of 
368 Kathmandu. If indeed the Mugnier et al. (2005) site records multiple events, it might 369 even also be speculated that one of the events correlates to the $1505 \mathrm{AD}$ earthquake.

370 About $100 \mathrm{~km}$ further west of the Mugnier et al. (2005) site and on a section of the 371 Main Boundary Thrust, which is generally considered to sole into the same decollement 372 as the HFT (Fig. 1), Hossler et al. (2015) interpret $8 \mathrm{~m}$ offsets of river terraces to record 373 surface ruptures subsequent to $1860 \mathrm{BP}$ and $640 \mathrm{BP}$, respectively, and conjecture that the 374 latter of these two could have been produced in the 1505 earthquake. Equally, the post $375640 \mathrm{AD}$ of Hossler et al. (2015) event can be considered to have occurred simultaneously 376 with a large paleoearthquake recognized by Murphy et al. (2014) yet farther north on a 377 strike-slip fault in the high Himalaya between 1165 AD and 1400 AD serves to illustrate 378 the large uncertainty in assigning the post 640 BP earthquake to a particular historical 379 account. One could even speculate that the 1221 AD to $1262 \mathrm{AD}$ surface rupture event 380 we observe at Tribeni extended westward through the Mugnier et al. (2005) site and 381 onwards and over to the Hossler et al. (2015) site on the MBT. Age constraints are so 382 limited that opportunities for correlation are somewhat without bound. All of these 383 384 Nonetheless, the Hossler et al. (2015) study shows that large earthquakes on out of 385 sequence thrusts can also accommodate convergence along the Himalayan front.

386 Continuing westward, a paleoseismic investigation along the HFT reported in the 387 abstract of Yule et al. (2006) has been cited by many (e.g., Hossler et al., 2015) to 388 confirm that rupture occurred near the west Nepal border in 1505, and a number of 389 similar investigations at sites along the HFT yet farther west in India may be consistent 390 with that idea (Kumar et al., 2006). If both the Yule et al. (2006) and Hossler et al. 391 (2014) sites record the same earthquake (e.g. 1505 A.D.), the observations would again 392 imply that rupture jumped between or was divided between both the MBT and HFT. 393 Because of the limited age control and distance of the two sites from historical accounts 394 of shaking, the idea that displacements at each site occurred simultaneously or, moreover, 395 both occurred during $1505 \mathrm{AD}$ is again, while perhaps thought-provoking, speculative.

396 Bringing the discussion back to the possible extent of the large 1221 - 1262 AD 397 displacement we see at Tribeni, it seems reasonable to consider that the earthquake that 398 produced the Tribeni scarp may have extended 150 kilometers westward in light of the 
observations recorded at the site of Mugnier et al.'s (2005) study (Fig. 1). A possible correlation of the large displacement on the MBT recognized by Hossler et al. (2015)

401 with either the $1221-1262$ AD Tribeni event or the historically reported 1505 AD event

402 is problematic because there exists only a lower limiting age on the timing of

403 displacement and that age is a very much older $640 \mathrm{BC}$. The observed large displacement

404 does though show that convergence across the Himalayan front can be shared between

405 the MBT and HFT, at least at the longitude of Hossler et al's. (2005) study (Fig. 1).

406 Finally, it may be said on the basis of Yule et al.'s (2006) study reported in abstract that

407 the HFT in westernmost Nepal does not share the same earthquake history as Tribeni.

408 3.7. Aspects of Earthquake Recurrence at Bagmati and Tribeni

409 Convergence between India and Tibet accumulates as elastic strain at the transition

410 from steady state creep located about $100 \mathrm{~km}$ north of the HFT beneath the high

411 Himalaya to the locked portion of the decollement to the south (Ader et al., 2012; Bilham

412 et al., 1998), which is intermittently released in large and great earthquakes (Bilham et

413 al., 1997; Kumar et al., 2008, 2010; Molnar and Pandey, 1989). The Gorkha earthquake

414 did initiate near this transition but rupture reached no closer than about $50 \mathrm{~km}$ to the trace

415 of the HFT to the south. In so doing, it has transferred stress and further loaded the

416 unruptured $\left(\sim 140 \times 50 \mathrm{~km}^{2}\right)$ section up-dip and to the south. Our studies at Tribeni and

417 Bagmati lend some insight to the past and possible future behavior of this unruptured 418 section of the HFT.

419 Geodesy shows that horizontal convergence is occurring at about $20 \mathrm{~mm} / \mathrm{yr}$ along 420 the Gorkha section of the Himalayan front (Ader et al., 2012) (Fig. 1), commensurate to $421 \quad 14-20 \mathrm{~m}$ and $15-16 \mathrm{~m}$ or shortening since since the offsets at Bagmati (1031-1321 422 AD) and Tribeni (1221 - 1262 AD). There is thus currently sufficient stress accumulated 423 in the crust to produce a very large earthquake, perhaps approaching Mw 9 with rupture 424 length on the order of $900 \mathrm{~km}$ (Blaser et al., 2010; Leonard, 2010, 2014; Strasser et al., 425 2010). If we are not recognizing younger offsets at Tribeni or Bagmati or on other out of 426 sequence thrusts to north, the calculated accumulated strain would be accordingly less. 427 We are aware of no studies between Tribeni and Bagmati bearing on this issue and the 428 historical chronicle of earthquakes of Pant (2002) is insufficient to assess with confidence 429 the size or location of any such events. 
On may address whether or not accumulated strain is currently sufficient to produce displacements of the size registered at Bagmati and Tribeni in (1031-1321 AD) and (1221

$432-1262$ AD), respectively. The fault scarps at Tribeni and Bagmati strike about $160^{\circ}$ (Fig.

433 2) and the direction of shortening defined by geodesy is about $190^{\circ}$ (Fig. 1 and e.g., Ader 434 et al., 2012). With this obliquity, only one half of the $20 \mathrm{~mm} / \mathrm{yr}$ geodetic convergence 435 might be expected to produce fault normal displacement and uplift. The vertical 436 separation expected along each of the scarps were they to rupture in releasing 437 accumulated strain can be estimated by multiplying the shortening rate $(10 \mathrm{~mm} / \mathrm{yr})$ by the 438 tangent of the fault dip at the scarp and the time since creation of the event horizons 439 documented for the last earthquake at Bagmati (1031 - 1321 AD) and Tribeni (1221 4401262 AD). Assuming a possible range of fault dips between $15^{\circ}-45^{\circ}$, the exercise leads 441 to values of 2 to $8 \mathrm{~m}$ at Tribeni and 1.9 to $9.9 \mathrm{~m}$ at Bagmati. If one assumes the fault dips 442 at the base of the Tribeni $\left(\sim 25^{\circ}\right)$ and Bagmati $\left(\sim 30^{\circ}\right)$ trenches continue downward 443 without change, the values calculated are $3.5-3.7 \mathrm{~m}$ and $4-5.7 \mathrm{~m}$, respectively. The 444 computed values at Tribeni encompass the 5-7 m vertical separation interpreted to have 445 occurred in $1221-1262 \mathrm{AD}$, and less if the dip observed in the trench $\left(\sim 25^{\circ}\right)$ extends 446 beneath the scarp. The range of values at Bagmati is less than the $10 \mathrm{~m}$ vertical separation 447 observed across the scarp there, though if the scarp has been produced by two events, it 448 also possible that the calculated range of uplift values encompasses the vertical separation 449 that occurred 1031 - 1321 AD. It is thus difficult with the limited observations to 450 establish exactly where the HFT sits within the strain accumulation cycle leading up to a 451 possible repeat of the offsets observed at Tribeni and Bagmati. And additional 452 uncertainty exists because there are to our knowledge no existing geological studies that 453 rule out displacement has also occurred on an out of sequence thrust to the north of 454 Tribeni and Bagmati (e.g. the MBT) since 1221 - 1262 AD, and historical data are too 455 limited to confirm or deny such a hypothesis. Nonetheless, the observations in hand do 456 provide reason to suggest that sufficient slip is stored in the system to produce a very 457 large earthquake along the section of HFT that includes Tribeni and Bagmati.

458 Another clue toward ultimately understanding earthquake recurrence along this 459 section of the HFT is recorded in the 801 - 541 BC age of the stratigraphically lowest 460 sample B-19 in the dip panel of the Bagmati exposure (Fig. 4b). From its location and 
461 age, it may be said that the sediments of unit 2 were deposited on a flat lying surface of 462 transport and aggradation absent of earthquake deformation for the period extending from 463 or before 801 - $541 \mathrm{BC}$ to 1310 - $1413 \mathrm{AD}$, the age of sample B15 (Fig. 4b). This 464 suggests that the recurrence time between the penultimate and 1031 - 1321 AD 465 earthquake at Bagmati exceeded $\sim 1572$ to 2122 years, significantly greater than the $\sim 695$ 466 to 985 years since the 1031 - $1321 \mathrm{AD}$, the bounding ages on formation of the Bagmati 467 scarp (Fig.5b).

\section{3.8. Synthesis of past and possible future ruptures}

469 We venture in Fig. 6 to graphically portray a plausible sequence of past and 470 possible future ruptures along the HFT in the vicinity of the Gorkha earthquake based on

471 the observations presented. The history begins with a large surface rupture event in $472 \sim 1100$ AD that extended eastward from Marha Khola for an unknown distance (Fig. 6a). 473 Allowing that Tribeni and Bagmati ruptured simultaneously, the entire section of the 474 HFT extending westward from Marha Khola, including Bagmati and Tribeni, is 475 interpreted to have ruptured in $1221 \mathrm{AD}$ - $1262 \mathrm{AD}$ (perhaps the $1255 \mathrm{AD}$ earthquake) 476 (Fig. 6b). The M 8.4 Bihar earthquake of 1934 subsequently re-ruptured all or part of the $477 \sim 1100$ AD rupture (Fig. 6c). The most recent 2015 Gorkha earthquake ruptured a small 478 down dip portion of the HFT that was perhaps previously broken in 1031 AD - 1321 AD 479 (1255 AD?) (Fig. 6d). Influenced by observation that shows us the Tribeni site may be 480 approaching or in the later stages of strain accumulation before a large earthquake, the 481 scenario hypothesizes that the next great earthquake may initiate to the west near Tribeni 482 and propagate into the section of fault beneath Kathmandu that did not rupture during the 4832015 Gorkha earthquake (Fig. 6e). The length of such a rupture would be $\sim 200 \mathrm{~km}$ or 484 greater and capable of producing an M8 earthquake or greater.

485 The preceding scenario of Fig. 6 is not unique. One may consider scenarios 486 whereby the Bagmati scarp is the product of two earthquakes in $1100 \mathrm{AD}$ and $1255 \mathrm{AD}$, 487 respectively (Fig. S7a), or a single event in $\sim 1100$ AD (Fig S7b). Regardless of the 488 model, each must embody the observation that, up-dip of the Gorkha earthquake at 489 Bagmati and to the west towards and perhaps past Tribeni, (1) sufficient time has passed 490 along the HFT to accumulate significant slip since the last earthquake, (2) that the size of 491 displacements at Bagmati and Tribeni are likely associated with ruptures of $200 \mathrm{~km}$ or 
492 more, and (3) it is plausible that Bagmati and Tribeni will rupture simultaneously in the

493 future because they either ruptured simultaneously in the past at 1255 AD or close in 494 time at $\sim 100 \mathrm{AD}$ and $1255 \mathrm{AD}$. Finally, there are other historically recorded 495 earthquakes in the region that may have influenced the past history of earthquakes, such 496 as the M7.5-7.9 earthquake 1833 earthquake (Fig. 1 and Bilham, 1995). We do not 497 include them in the scenario of Fig. 6 because it is not certain that they occurred on the 498 HFT.

\section{4. Conclusion}

500 The sum of observations suggest that the HFT extending $\sim 200 \mathrm{~km}$ from Tribeni to 501 Bagmati may rupture simultaneously, that the next great earthquake near Kathmandu may 502 rupture an area significantly greater than the section of HFT up dip from the Gorkha 503 earthquake (Figure 6), and that it is prudent to consider that the HFT near Kathmandu is 504 well along in a strain accumulation cycle prior to a great thrust earthquake, much greater 505 than occurred in 2015. In these regards, the 2015 Gorkha earthquake did not diminish the 506 current level of seismic hazard in Kathmandu.

\section{Acknowledgements}

508 We thank Greg Hodkins, Rebecca Watson, and Richard Cruz at the University of Arizona

509 AMS Lab for prompt analysis obtaining the highest precision dates possible. Discussions 510 with Glenn Biasi concerning radiocarbon and OxCal were most insightful. We thank

511 Roger Bilham and two external reviewers for comments and An Yin for handling the 512 manuscript. The Director General and Officers at the Department of National Park and 513 Wildlife Conservation, Government of Nepal permitted us to conduct research in the 514 Chitwan National Park, Tribeni. Bhim Raj Sedai at Tribeni Post of Chitwan National

515 Park supported permitting and excavation. The support of the Community Forest User 516 Group is greatly acknowledged. The research is supported by NSF Grant EAR-1345036 517 to SGW. CNS Contribution 69. 


\section{References}

524 Ader, T., Avouac, J.P., Liu-Zeng, J., Lyon-Caen, H., Bollinger, L., Galetzka, J., Genrich,

525 J., Thomas, M., Chanard, K., Sapkota, S.N., Rajaure, S., Shrestha, P., Ding, L.,

526 Flouzat, M., 2012. Convergence rate across the Nepal Himalaya and interseismic

527 coupling on the Main Himalayan Thrust: Implications for seismic hazard. Journal of

528 Geophysical Research-Solid Earth 117.

529 Ambraseys, N., Jackson, D., 2003. A note on early earthquakes in northern India and 530 southern Tibet. Current Science 84, 570-582.

531 Anderson, E.M., 1951. The dynamics of faulting. Oliver and Boyd, Edinburgh.

532 Angster, S., Fielding, E.J., Wesnousky, S., Pierce, I., Chamlagain, D., Gautam, D., 533 Upreti, B.N., Kumahara, Y., Nakata, T., 2015. Field reconnaissance after the 25 April 5342015 M 7.8 Gorkha earthquake. Seismological Research Letters 86, 1506-1513.

535 Avouac, J.-P., Meng, L., Wei, S., Wang, T., Ampuero, J.-P., 2015. Lower edge of locked 536 Main Himalayan Thrust unzipped by the 2015 Gorkha earthquake. Nature Geoscience $5378,708-+$.

538 Bilham, R., 1995. Location and magnitude of the 1833 Nepal earthquake and its relation 539 to the rupture zones of contiguous great Himalayan earthquakes. Current Science 69, $540 \quad 155-187$.

541 Bilham, R., 2004. Earthquakes in India and the Himalaya: tectonics, geodesy and history. $542 \quad$ Annals of Geophysics 47, 839-858.

543 Bilham, R., Blume, F., Bendick, R., Gaur, V.K., 1998. Geodetic constraints on the 544 translation and deformation of India: Implications for future great Himalayan 545 earthquakes. Current Science 74, 213-229.

546 Bilham, R., Larson, K.M., Freymueller, J., members, P.I., 1997. GPS measurements of 547 present day convergence across the Nepal himalaya. Nature 386, 61-64.

548 Blaser, L., Krueger, F., Ohrnberger, M., Scherbaum, F., 2010. Scaling Relations of 549 Earthquake Source Parameter Estimates with Special Focus on Subduction 550 Environment. Bulletin of the Seismological Society of America 100, 2914-2926. 
551 Bollinger, L., Sapkota, S.N., Tapponnier, P., Klinger, Y., Rizza, M., Van der Woerd, J., 552 Tiwari, D.R., Pandey, R., Bitri, A., de Berc, S.B., 2014. Estimating the return times of 553 great Himalayan earthquakes in eastern Nepal: Evidence from the Patu and Bardibas 554 strands of the Main Frontal Thrust. Journal of Geophysical Research-Solid Earth 119, $555 \quad 7123-7163$.

556 Bollinger, L., Tapponnier, P., Sapkota, S.N., Klinger, Y., 2016. Slip deficit in central 557 Nepal: omen for a repeat of the 1344 AD earthquake? Earth Planets Space 68.

558 Bronk, R., 2009. Bayesian analysis of radicarbon dates. Radiocarbon 51, 337-360.

559 Elliott, J.R., Jolivet, R., Gonzalez, P.J., Avouac, J.P., Hollingsworth, J., Searle, M.P., 560 Stevens, V.L., 2016. Himalayan megathrust geometry and relation to topography 561 revealed by the Gorkha earthquake. Nature Geoscience 9, 174-+.

562 Ellis, S., Schreurs, G., Panien, M., 2004. Comparisons between analogue and numerical 563 models of thrust wedge development. Journal of Structural Geology 26, 1659-1675.

564 Hayes, G.P., Briggs, R.W., Barnhart, W.D., Yeck, W.L., McNamara, D.E., Wald, D.J., 565 Nealy, J.L., Benz, H.M., Gold, R.D., Jaiswal, K.S., Marano, K., Earle, P.S., Hearne, 566 M.G., Smoczyk, G.M., Wald, L.A., Samsonov, S.V., 2015. Rapid Characterization of the 2015 M-w 7.8 Gorkha, Nepal, Earthquake Sequence and Its Seismotectonic

569 Hossler, T., Bollinger, L., Sapkota, S.N., Lave, J., Gupta, H.K., Kandel, T.P., 2015.

570 Surface ruptures of large Himalayan earthquakes in western Nepal: Evidence along a reactivated strand of the Main Boundary Thrust. Earth and Planetary Science Letters

573 Hough, S.E., Bilham, R., 2008. Site response of the Ganges basin inferred from re574 evaluated macroseismic, observations from the 1897 Shillong, 1905 Kangra, and 575

576 Jackson, D., 2002. The great western-Himalayan earthquake of 1505: A rupture of the 577 central Himalayan Gap?, Tibet, past and present: Tibetan studies 1; Proceedings of 578 the ninth seminar of the International Association for Tibetan Studies, Leiden, $579 \quad$ Netherlands, pp. 147-158. 
580 Kumar, S., Wesnousky, S.G., Jayangondaperumal, R., Nakata, T., Kumahara, Y., Singh, 581 V., 2008. Paleoseismological evidence of surface faulting along the northeastern 582 Himalayan front, India. Himalayan Geology 29, 46-46.

583 Kumar, S., Wesnousky, S.G., Jayangondaperumal, R., Nakata, T., Kumahara, Y., Singh, 584 V., 2010. Paleoseismological evidence of surface faulting along the northeastern 585 Himalayan front, India: Timing, size, and spatial extent of great earthquakes. Journal of Geophysical Research-Solid Earth 115.

587 Kumar, S., Wesnousky, S.G., Rockwell, T.K., Briggs, R.W., Thakur, V.C., 588 Jayangondaperumal, R., 2006. Paleoseismic evidence of great surface rupture 589 earthquakes along the Indian Himalaya. Journal of Geophysical Research-Solid Earth

591 Lave, J., Avouac, J.P., 2001. Fluvial incision and tectonic uplift across the Himalayas of 592 central Nepal. Journal of Geophysical Research-Solid Earth 106, 26561-26591.

593 Lave, J., Yule, D., Sapkota, S.N., Basant, K., Madden, C., Attal, M., Pandey, R., 2005.

594 Evidence for a Great Medieval Earthquake ( 1100 A.D.) in the Central Himalayas, $595 \quad$ Nepal. Science 307, 1302-1305.

596 Leonard, M., 2010. Earthquake Fault Scaling: Self-Consistent Relating of Rupture 597 Length, Width, Average Displacement, and Moment Release. Bulletin of the 598 Seismological Society of America 100, 1971-1988.

599 Leonard, M., 2014. Self-Consistent Earthquake Fault-Scaling Relations: Update and 600 Extension to Stable Continental Strike-Slip Faults. Bulletin of the Seismological 601 Society of America 104, 2953-2965.

602 Molnar, P., Pandey, M.R., 1989. Rupture zones of great earthquakes in the Himalaya 603 region. Earth Plan. Sci. 98, 61-70.

604 Mugnier, J.L., Huyghe, P., Gajurel, A.P., Becel, D., 2005. Frontal and piggy-back 605 seismic ruptures in the external thrust belt of Western Nepal. Journal of Asian Earth $606 \quad$ Sciences 25, 707-717.

607 Murphy, M.A., Taylor, M.H., Gosse, J., Silver, C.R.P., Whipp, D.M., Beaumont, C., 608 2014. Limit of strain partitioning in the Himalaya marked by large earthquakes in 
western Nepal. Nature Geoscience 7, 38-42.

610 Nakata, T., Upreti, B.N., Kumahara, Y., Yagi, H., Okumura, K., Rockwell, T.K., Virdi, 611 N.S., 1998. First successful paleoseismic trench study on active faults in the 612 Himalaya. EOS, Trans. 79, F615.

613 NCEDC, 2014. ANSS composite catalog. Northern California Earthquake Data Center, 614 UC Berkeley Seismological Laboratory Data set. doi:10.7932/NCEDC

615 Pandey, M.R., Molnar, P., 1988. The distribution of intensity of the Bihar-Nepal 616 earthquake of 15 January 1934 and bounds on the extent of the rupture zone. J. Geol. $617 \quad$ Soc. of Nepal 5, 22-44.

618 Pant, M.R., 2002. A step towards a historical seismicity of Nepal, ADARSA. Pundit 619 publications, Kathmandu, pp. 29-60.

620 Reimer, P.J., Bard, E., Bayliss, A., Beck, J.W., Blackwell, P.G., Ramsey, C.B., Buck, 621 C.E., Cheng, H., Edwards, R.L., Friedrich, M., Grootes, P.M., Guilderson, T.P., 622 Haflidason, H., Hajdas, I., Hatte, C., Heaton, T.J., Hoffmann, D.L., Hogg, A.G., 623 Hughen, K.A., Kaiser, K.F., Kromer, B., Manning, S.W., Niu, M., Reimer, R.W., 624 Richards, D.A., Scott, E.M., Southon, J.R., Staff, R.A., Turney, C.S.M., van der 625 Plicht, J., 2013. INTCAL13 and marine13 radiocarbon age calibration curves 062650,000 years Cal Bp. Radiocarbon 55, 1869-1887.

627 Sapkota, S.N., Bollinger, L., Klinger, Y., Tapponnier, P., Gaudemer, Y., Tiwari, D., 628 2013. Primary surface ruptures of the great Himalayan earthquakes in 1934 and 1255. 629 Nature Geoscience 6, 71-76.

630 Strasser, F.O., Arango, M.C., Bommer, J.J., 2010. Scaling of the Source Dimensions of 631 Interface and Intraslab Subduction-zone Earthquakes with Moment Magnitude. 632 Seismological Research Letters 81, 941-950.

633 Upreti, B.N., Nakata, T., Kumahara, Y., Yagi, H., Okumura, K., Rockwell, T.K., Virdi, 634 N.S., 2000. The latest active faulting in Southeast Nepal, Proceedings of the Hokudan 635 International Symposium and School in Active Faulting, Awaji Island, Hyogo Japan, 636 p. $533-536$.

637 Yule, D., Dawson, S., Lave, J., Sapota, S.N., Tiwari, D.R., 2006. Possible evidence for 

Meeting.
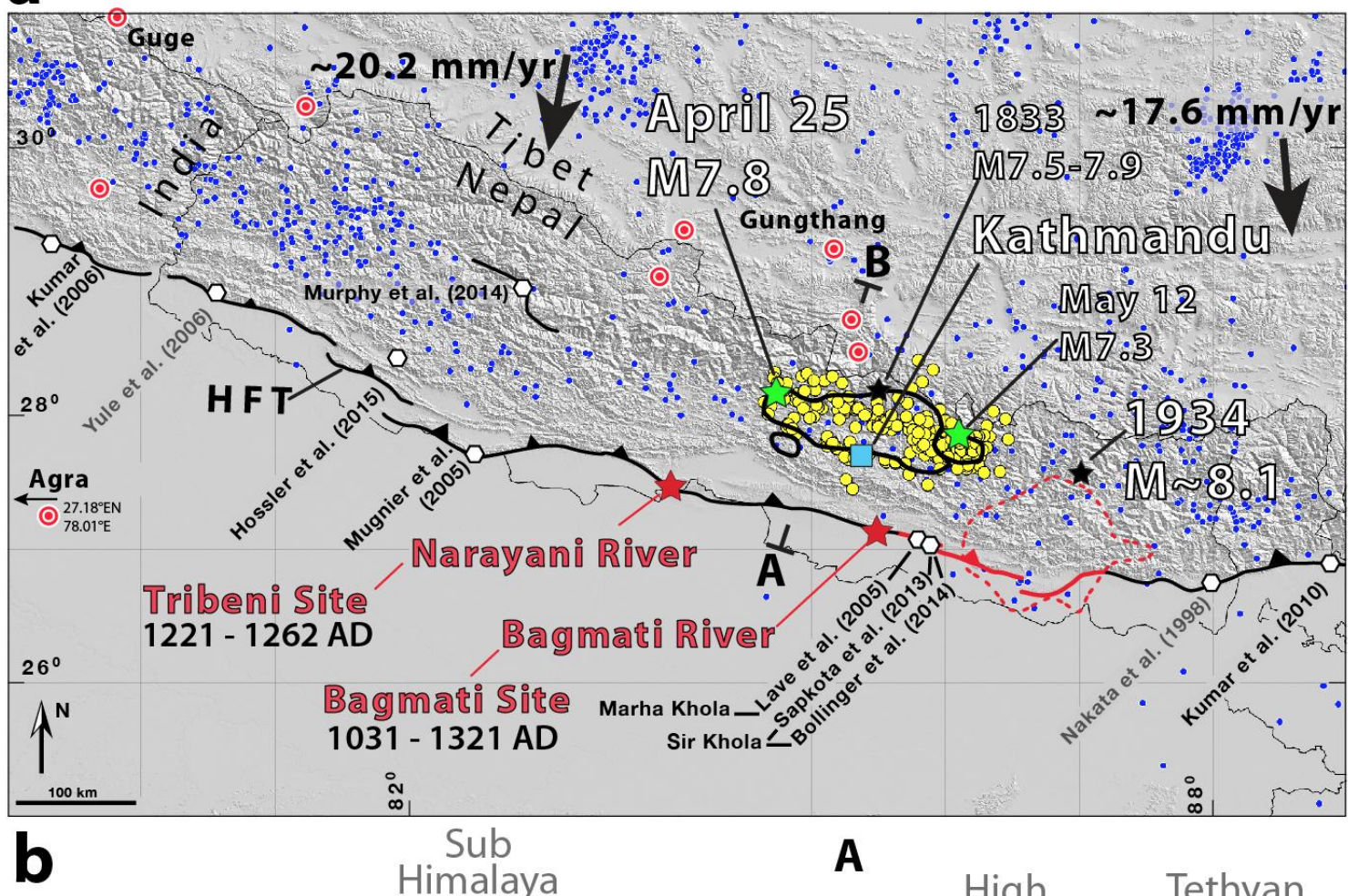

Gangetic Plain | | Lesser Himalaya | Himalaya | Himalaya

645

646

647

648

Figure 1. (a) Locations (red stars) of Tribeni and Bagmati paleoseismic study sites along

649 Narayani and Bagmati rivers in Nepal. Green Stars: Epicenters of 2015 Gorkha 650 earthquake mainshock (M7.8) and largest aftershock (M7.3). Himalayan Frontal 651 Thrust (HFT) is represented by solid black line with triangles on hanging wall. The 
652 extent of surface rupture along HFT during the Mw8.4 1934 earthquake propososed 653 by Bollinger et al. (2014) is colored red. Yellow dots: Epicenters of M>4 aftershocks 654 taking place within 1 day of Gorkha mainshock (National Seismological Center, 655 Nepal;http://www.seismonepal.gov.np/index.php?action=earthquakes\&show=recent). 656 Blue dots: Locations of $\mathrm{M}>4$ earthquakes prior to Gorkha earthquake since 1968 657 taken from ANSS catalog (NCEDC, 2014). Black Stars: Epicenters assessed from 658 analysis of felt reports of prior large 1833 (M7.5-7.9) and 1934 (M 8.1) Bihar 659 earthquakes from Bilham (1995) and Hough and Bilham (2008), respectively. Closed 660 solid lines adapted from Hayes et al. (2015) delimit area of HFT that slipped in the 661 Gorkha earthquake. Closed dashed red line: Area of isoseismal VIII (MSK64) for 6621934 Bihar earthquake taken from Sapkota et al.'s (2013) interpretation of reports in 663 Pandey and Molnar (1988). Thick black line with triangles: Location of Himalayan 664 Frontal Thrust (HFT), triangles on hanging wall. White dots: Locations and citations 665 of prior paleoseismological studies mentioned in text. Red dots: Locations of damage 666 reported by Ambraseys and Jackson (2003) and used to interpret the occurrence of a $667 \sim \mathrm{M} 8.3$ earthquake in western Nepal on June 6, 1505. Arrows schematically illustrate 668 GPS results of Ader et al. (2012) that show elastic strain equivalent to 17 to 20 $669 \mathrm{~mm} / \mathrm{yr}$ of convergence is accumulating beneath the High Himalaya. (b) Generalized 670 cross-section extends along trend $\mathrm{AB}$ (shown in upper figure) is adapted from Lave 671 and Avouac (2001) and shows approximate extent of rupture during Gorkha 672 earthquake (red line) and relocated aftershocks reported in Hayes et al. (2015) 673 (yellow circles). Convergence of the Indian and Eurasian plates has been 674 accommodated by thrust motion along the Himalayan Frontal Thrust (HFT) and the 675 Main Boundary Thrust (MBT), which coalesce into a single decollement beneath the 676 High Himalaya and Tibet. 

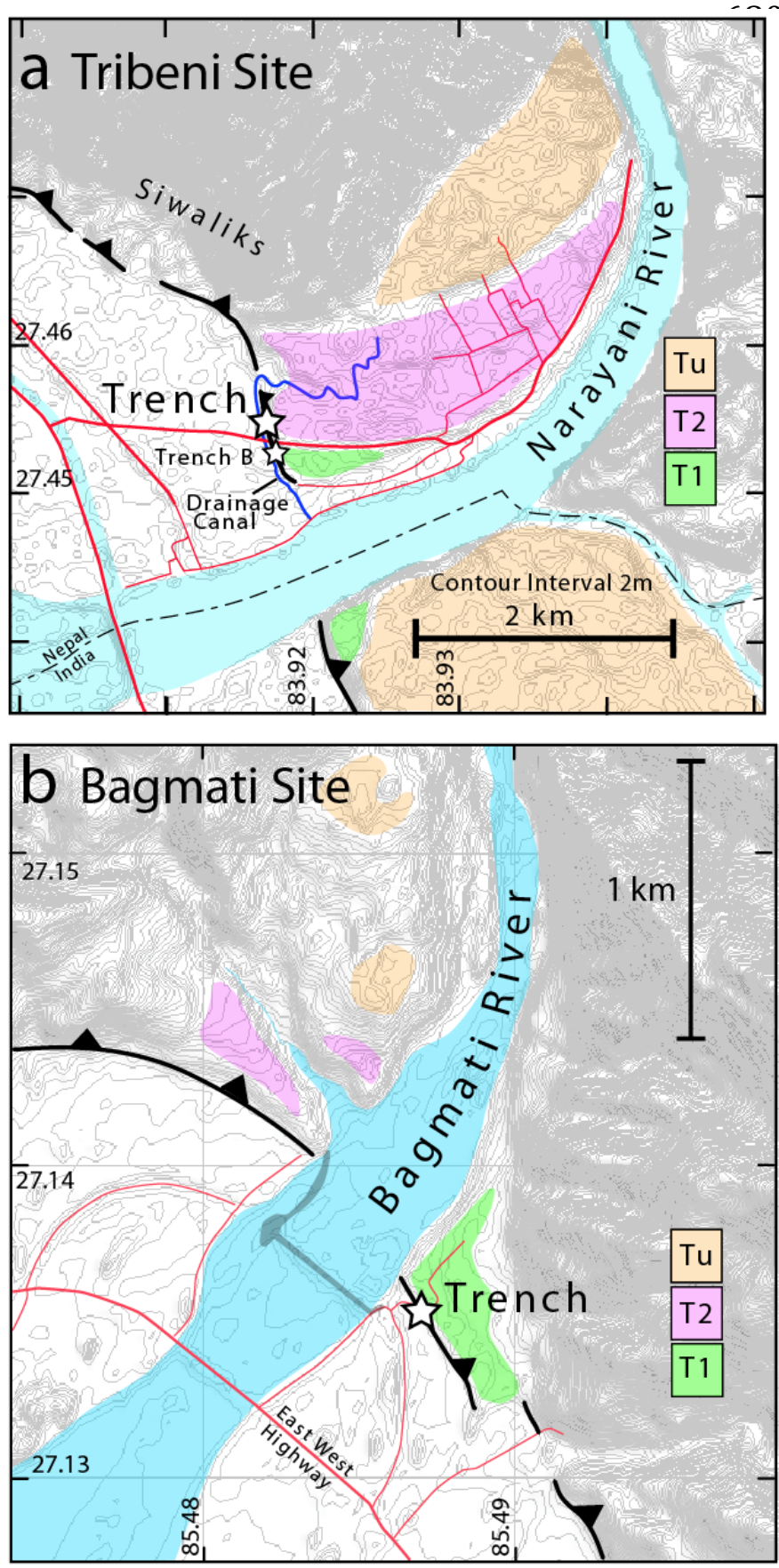

711

712

713

714

715

716

717
Figure 2. Location of (a) Tribeni and (b) Bagmati trench sites (stars) each on $2 \mathrm{~m}$ contour base map (constructed from SRTM 1 Arc-Second Global data downloaded from http://earthexplorer.usgs.gov). $\mathrm{T} 1$ and $\mathrm{T} 2$ at each site are fluvial terrace deposits of relatively increasing age that are truncated and uplifted by displacement on the Himalayan Frontal Thrust (thick line with triangles on hanging wall). Possibly correlative and higher older surfaces are labeled Tu. Locations of trenches are labeled and marked by stars. The meandering blue line on T2 north of the Narayani River at Tribeni marks course of small drainage that has been deflected by human emplacement of a levee to produce a drainage canal that runs parallel to the fault scarp which marks trace of Himalayan Frontal Thrust. Waypoints of Tribeni Trench and Trench B are $27.454183^{\circ} \mathrm{N}$ , $\quad 83.916620^{\circ} \mathrm{E}$ and $27.451748^{\circ} \mathrm{N}, \quad 83.917412^{\circ} \mathrm{N}$, respectively, and the trench at Bagmati 27.134254 ${ }^{\circ}$, $85.487735^{\circ}$. The elevation difference between the footwall of the Bagmati trench $(\sim 135 \mathrm{~m})$ and current river level $(\sim 127$ 
$718 \mathrm{~m})$ is $\sim 8 \mathrm{~m}$. The elevation difference between the footwall of the Tribeni trenches $719 \quad(\sim 120 \mathrm{~m})$ and current river level $(\sim 120 \mathrm{~m})$ is $6 \mathrm{~m}$.

720

721 

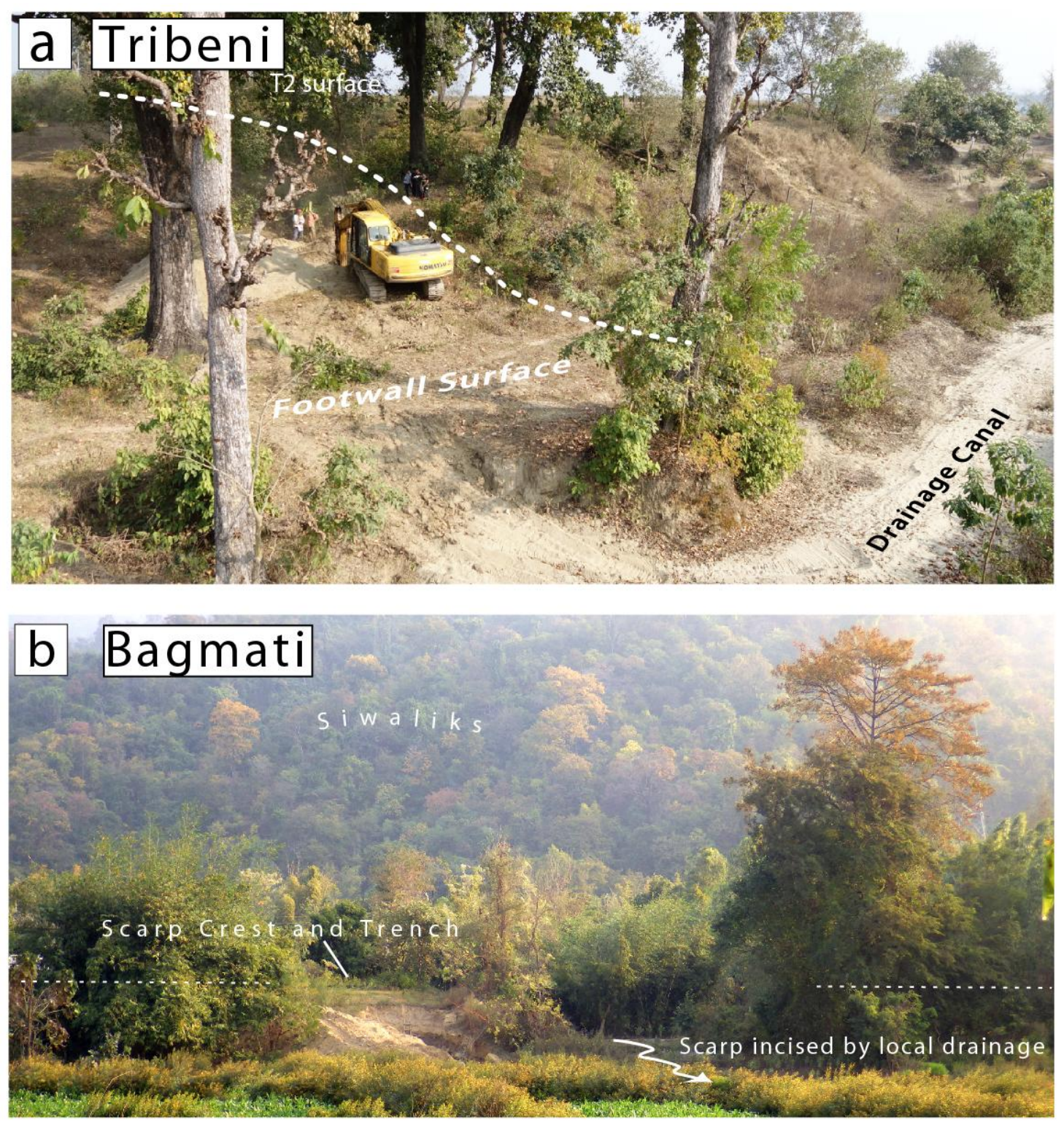

724 Figure 3. Photos illustrate character of scarps excavated at Bagmati and Tribeni sites. (a)

725 View is southeastward and taken from levee bounding drainage canal that is deflected 726 along the scarp at Tribeni (see Figure 2a). Dashed white line approximates scarp 727 profile and location of trench. (b) Southeastward view of trench site at Bagmati 728 shows it to be adjacent to local drainage that cuts approximately perpendicular to and 729 incises scarp. Dashed line marks crest of scarp where hidden in trees. 


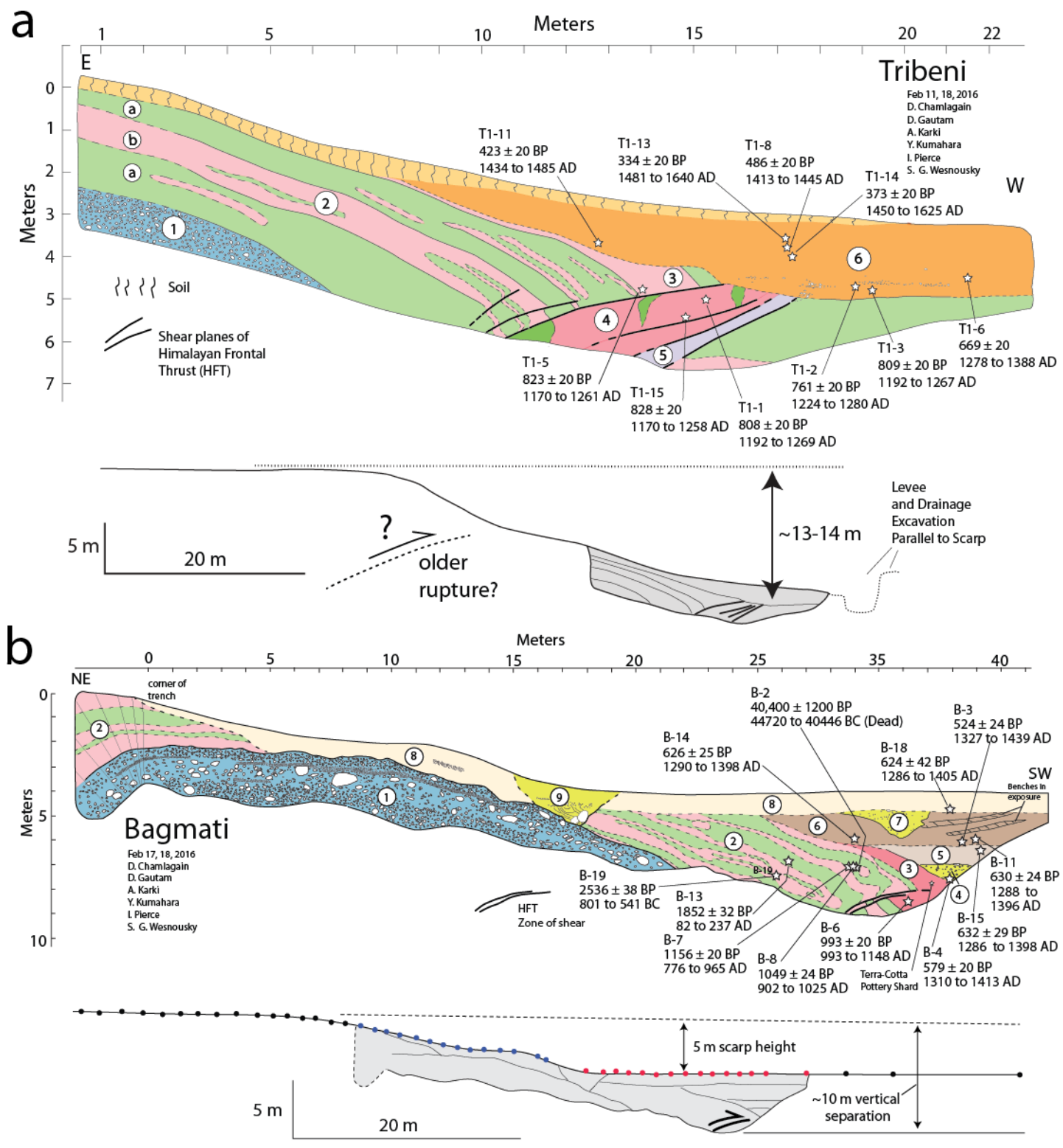

733 Figure 4. Trench logs at (a) Tribeni and (b) Bagmati. Location of trenches relative to profile of scarp across which they are excavated shown below each log. Numbers in circles are unit numbers. Detrital charcoal samples dated with radiocarbon are labeled and plotted with radiocarbon and corrected age bounds, each reported to $95 \%$ confidence limits (Supplementary Table S1). At Bagmati, blue and red dots mark upper and lower portions of trench log, respectively. Logistics related to property ownership required that the upper portion of trench be excavated, logged and filled prior to excavating, logging, and filling the lower portion of trench. Aspects of property ownership also limited the southwestward extent to which the trench was 
742 excavated. Scarp profiles at Tribeni and Bagmati measured with GPS receiver and 743 Total station vertical accuracy of $\sim 0.5 \mathrm{~m}$ and $\sim<3 \mathrm{~cm}$, respectively. Profile at Tribeni

744 is average of several across the scarp nearby because of stream incision adjacent to 745 trench site. Supplementary Materials include further description of units (Table S2) 746 and Photo Logs of each exposure (Figures S3, S4, S5, and S6). 


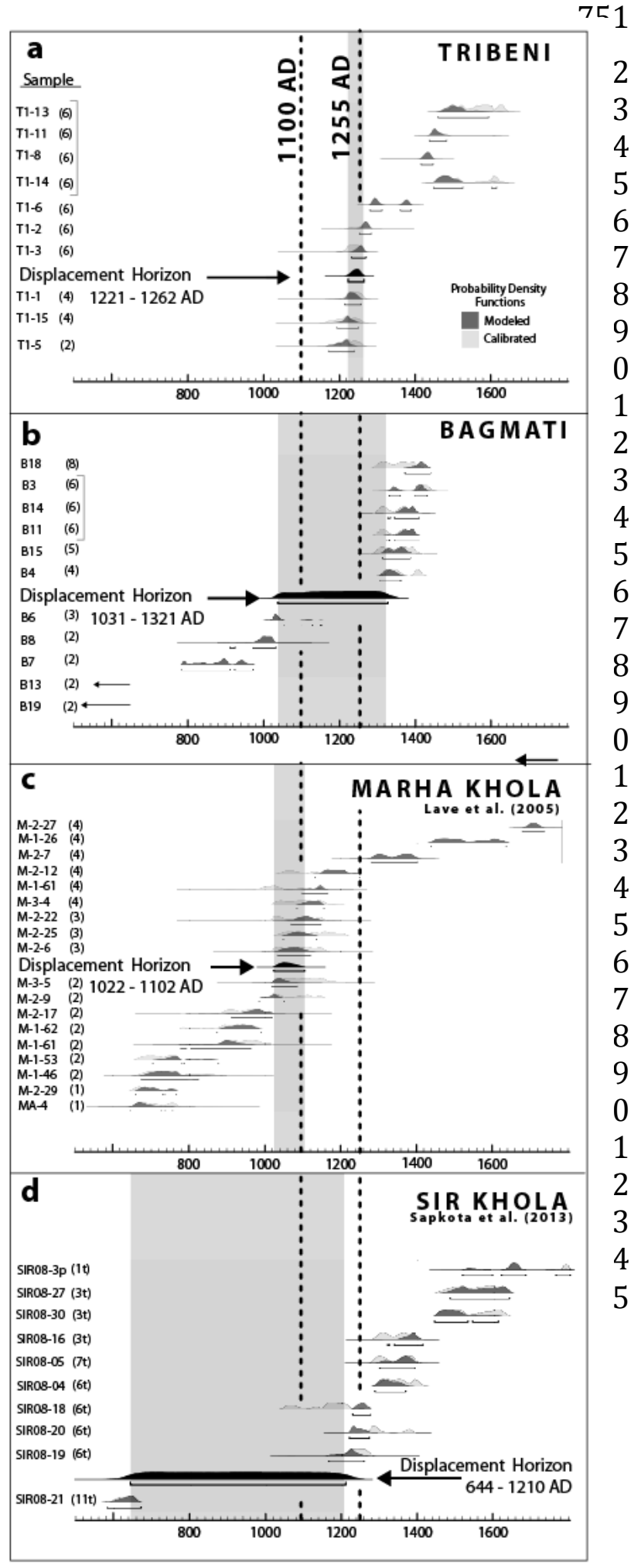

Figure 5. Radiocarbon ages of detrital charcoal samples in conjunction with structural and stratigraphic relationships exposed in trenches limit the time of last large earthquakes to produce surface rupture. Individual corrected and modeled ages of each sample are presented in stratigraphic order as probablility density distributions determined with OxCal v4.2.4 ((https://c14.arch.ox.ac.uk/oxcal/O xCal.html) Bronk, 2009) with the IntCal13 atmospheric curve of Reimer et al. (2013). Each sample number and stratigraphic unit number (in parentheses) is labeled and correlates to respective trench logs from which they were taken. Observations collected in this study at (A) Bagmati and (B) Tribeni are compared to results reported in prior nearby studies at (C) Marha Khola (Lave et al., 2005) and (D) Sir Khola (Sapkota et al, 2013), and arranged to progress eastward from $\mathrm{A}$ to $\mathrm{D}$. Grayed areas encompass temporal bounds on event at each site. Thick vertical dashed line corresponds to years $1100 \mathrm{AD}$ and $1255 \mathrm{AD}$ discussed in text. 

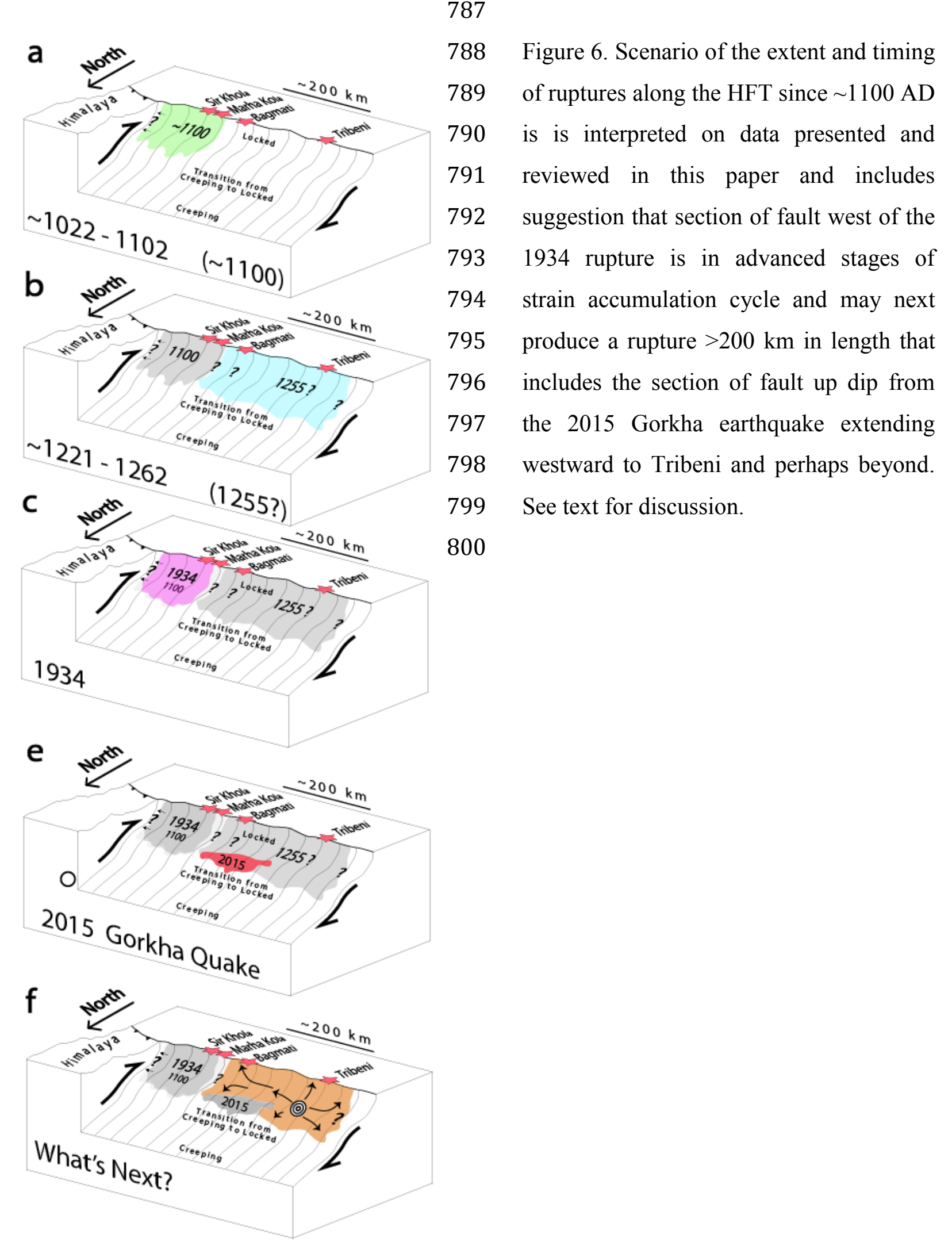


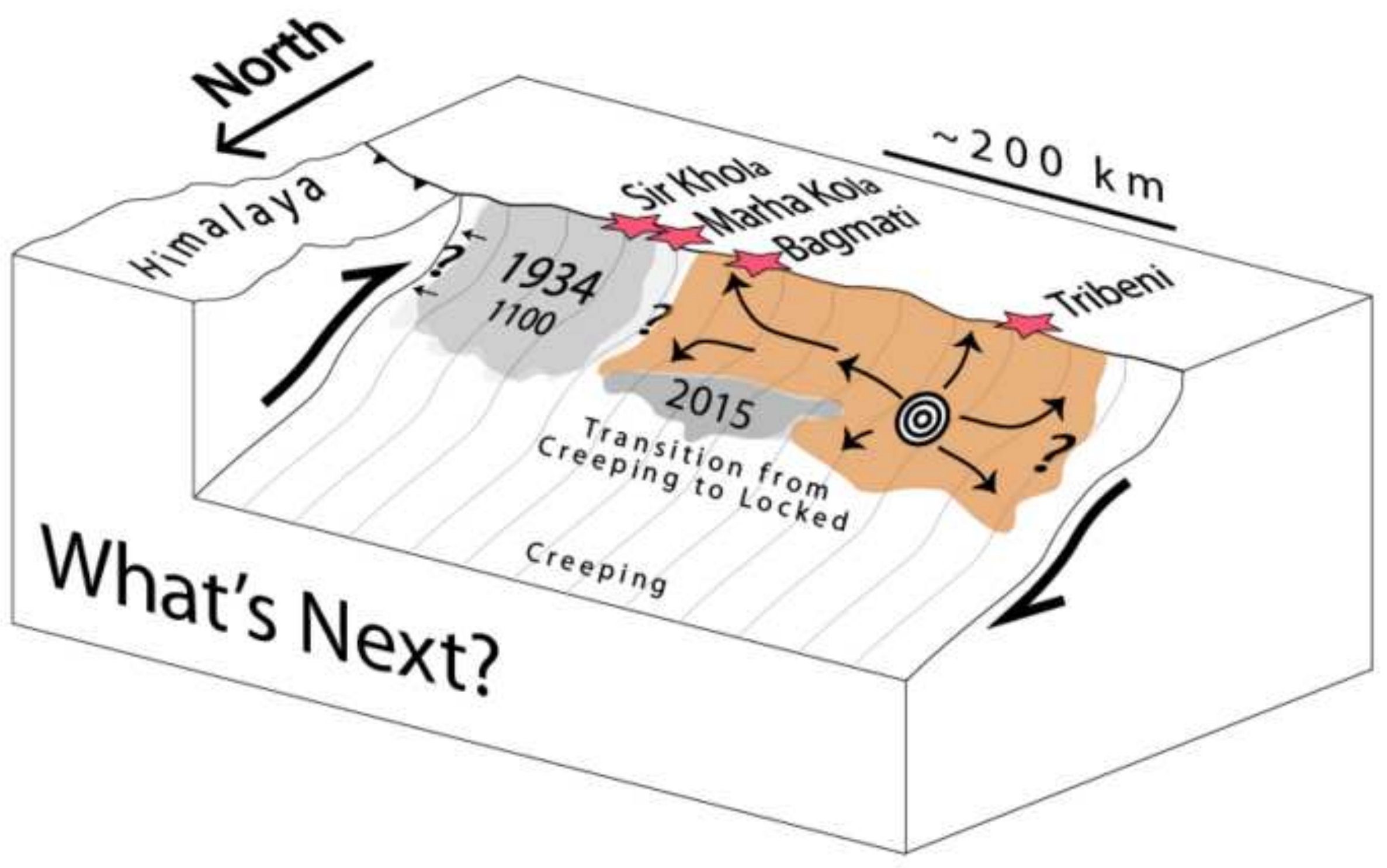

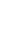

